\title{
THE AUTHOR'S TOOL
}

THE receipt of a bill from a Midland bookseller from whom I had made some purchases first drew my attention to this subject. The details in his bill of the books which had been ordered were written in a beautiful penmanship, and when the receipt arrived it was a pleasure to notice that the terms of acknowledgment were written in the same lettering as the printed name and address of the bookseller at the top of the sheet. Apparently the fount of type had been designed from his handwriting. This delighted me so much that I wrote a letter saying that I had not supposed it possible for anyone to add to the pleasure of an ordinary receipt, until my creditor had done so by presenting me with a distinguished example of penmanship. Thereupon the following letter arrived. It deserves to be quoted as a rare example of a simple, commercial transaction beautifully done. Readers, however, must be content with the substance which, stripped of its beautiful form, reads as follows :

"Dear Sir,

"Accept my thanks for your kind letter and remittance. Your words of praise gave me great pleasure, and I thank you for them. Caligraphy has been my delight since childhood, and is still my greatest joy and consolation. I get plenty of scribbling now, since I am almost alone in this little book-business, yet compared to the output of authorship my efforts are tiny in comparison."

Alas ! compared to the delicate page on which his words are written, what countless printed pages are put to shame. My correspondent had found the 


\section{The Author's Tool}

practice of penmanship not only a "delight since childhood," but a "consolation" in later life.

The author's tool then was no exception: its handling also had agreeable secrets of its own. Though my own handwriting is past blaming, I dipped into the subject and found that to acquire a good formal hand was, strictly speaking, the occupation of a lifetime. A hobby may become that to a sincere amateur of any subject, but a more cursory study will give to anyone a new delight in handwriting, a new pleasure in printed books, and make him pause to the surprise of other people over tombstones. The lettering upon an eighteenth century tombstone often raises it to the dignity of literature. These pleasures have brought in their train a friendship with a scribe, and made apparent certain elementary truths concerning the relation of penmanship to printing which, however obvious to professional students, are unheeded by the generality of writers. The gulf between writing and printing is now so wide that it requires a mental effort at first to form a bridge between them. Reading is a confirmed habit in an age of newspapers; groups of words are read rapidly in a single glance. Therefore it is hardly surprising that those who have lost the need to observe the shape of a letter should have become blind to that subtler thing, its form. Yet the early printed books drew their beauty from the manuscripts on which their founts of types were modelled; and soon after printing was established penmanship, handwriting, began to decay. Writers on the subject remark that there soon became no living model for the type-founders; and that the founts became debased till they reached their lowest point in the books printed in the first half of the past century. Handwriting had ceased to be the scholar's art, and at present a beautifully written letter, a letter even shewing care for clarity, spacing, and margin, 


\section{Blackfriars}

gives us mainly the pleasure of surprise. The consequences are many. : Authors write now not to be read, but to be printed; and no one who has been inside a printing office can doubt that if most manuscripts were printed as they are received they would be almost unintelligible. A certain well-known coroner, for instance, is indefatigible in sending detailed reports of his remarks to an editor of my acquaintance, but as these are scrawled on the back of the newspaper cutting which refers to the case in question, the trouble that he causes to other people is sufficient to occupy them for a lifetime. The horrible jargon of the newspapers, the prevalence of commercial metaphors, the grotesque and wild attempts at punctuation, these are some of the results which necessarily follow the neglect of handwriting.

Anyone who devotes a few hours even to the rudiments necessary for the acquisition of a formal hand will make some agreeable discoveries, some of which conflict with the canons of the schoolroom and copy-book. He will find at once that every effect does, indeed, depend upon the pen, and if he should happen to have a scribe among his friends he will become familiar with the lamentation that the pen "gave out" before a certain page was finished, and that painful hours were spent before a new one was cut to the nicety required by the texture of the paper obtainable. He will also learn that his governess had been unprofessional in teaching him never to remove the pen from the paper during the formation of a single letter, and that, for instance, such a simple letter as " $\mathrm{e}$ " was made by the early scribe in three strokes. It is interesting also to realize how the pen has controlled the form of letters, and to learn, pen in hand, that the apparent difference between the form of Roman capitals and that of small letters is not arbitrary, but that the smaller became what they are 


\section{The Author's Tool}

simply through the attempt of the writer to trace the capitals at a high speed. Authorities relate that some, if not all, of the famous manuscripts, like the Book of Kells, were not written slowly for all their care, but at a speed which was the reward of constant practice. It appears, too, that those who have revived the art of penmanship in England have learnt most of its secrets, as was to have been expected, from the use of the pen itself; and that certain beautiful serifs and hooks at the end of the stems or tails of letters can be formed only by a turn of the pen, which is a true sleight of hand, the perfection of long practice.

Unless people have a liking for early printed books or have handled manuscripts, a piece of script when first shewn to them conveys nothing but a puzzling sense of oddity. It seems to require an effort of the will to direct the eyes from the page to its component words, and from the words to the letters. Once this attention to detail has become the first object of interest, it is evident that almost every word, and certainly every line, has received separate attention. Two forms of the same letter will be used according to the presence or absence of letters with stems or tails in the same or an adjoining word; ampersands will be used at discretion; the cross strokes of " $t$ " at the end of lines will be long or short according to the length of the line itself compared with the length of others, and the whole page thereby gains an effect of balance, indeed of animation, which is the reverse of the ordinary uniformity of print. A page of script (and the same is true, but in a smaller degree, of fine printing) becomes alive and individual, with an interest and a character of its own. Soon the variety of the varied forms becomes delightfully familiar, and a challenge is opposed to the quality, the literary quality, of the text. Insincerity, nonsense, vulgarity is really made aware of itself when brought into the 


\section{Blackfriars}

beautiful prominence of fine lettering. Writing was once a vocation: penmanship the scholar's art; for the virtues of the scribe and of the writer are the same-correctness, distinctness and order. If, therefore, authors wrote to be read and not merely to be printed, would they not write better in a double sense ? Haste, inconsideration is the enemy, not only of penmanship, but of style.

Throughout, the influence of the tool, the actual pen, is seen to be potent. At first manuscripts would not have been laboriously copied (Thomas à Kempis, who belonged to the Brothers of the Common Life, had " an exquisite hand," and is said to have copied the whole Bible in four fat volumes with his own pen), unless they contained something which satisfied the imagination of.men. It was once customary that only scribes or Rabbis of great sanctity should be allowed to copy the sacred Christian or Jewish books. The form and content of literature were one. The effect of printing cannot be said to have improved the quality of either. It has made the best more accessible, and multiplied indefinitely the worst.

As the gulf widens between the art of literature and the craftsmanship of the pen, both lose and are oddly influenced by their loss. Of the decay of beautiful handwriting it is not necessary to speak ; and a modern well-designed fount of type comes to most of us with an air of self-consciousness which proves that our eyes have become impatient of observing the form of print. In the case of prose, of literature, it is enough to mention the slipshod style of most contemporary writers of repute; and when we look back to the crows of triumph which heralded the New Journalism of the eighties, our judgment begins to measure the degree of advantage in that change. The decay of handwriting gave encouragement to the typewriter ; the form of its letters was first conditioned by the 
need to make them all of the same width, and the typewriter has led the way to shorthand and encouraged the habit of dictation, which enables a man to write a book without ever putting pen to paper. The divorce is thus complete : haste becomes a habit. It is hardly too much to say that the click of the typewriter makes itself heard in the mechanical noise of a style such as that of Mr. Shaw, and a new light was thrown upon the later style of Henry James when it was recorded that the last involutions of his manner were encouraged when the practice of dictation grew upon him. Walter Pater's style developed with his habit of writing on alternate lines of ruled paper. In fine, although literature is the one art which possesses no handicraft, its result, like that of its more fortunate rivals, is still governed by the author's tool. Since, whether it be the pen, the typewriter, or the stenographer's pencil, that tool will control the result, the case seems clear that, at some time in their careers, men of letters should be writers. A lerger subject follows: the effect of printing on literature, and the degree to which literature is now controlled by the number of readers which the printing-press has placed within its reach. To that subject I hope to return in a subsequent paper.

OSBERT BuRdetT. 